\title{
Epidemiology of lymphocystis, epidermal papilloma and skin ulcers in common dab Limanda limanda along the west coast of Denmark
}

\author{
Stig Mellergaard ${ }^{1, *}$, Else Nielsen $^{2}$ \\ ${ }^{1}$ Danish Institute for Fisheries Research, Department for Marine and Coastal Zone Ecology, Fish Disease Laboratory, \\ Bülowsvej 13, DK-1870 Frederiksberg C, Denmark \\ ${ }^{2}$ Danish Institute for Fisheries Research, Department for Marine and Coastal Zone Ecology, Charlottenlund Castle, \\ DK-2920 Charlottenlund, Denmark
}

\begin{abstract}
A survey of fish diseases in the common dab Limanda limanda L. was conducted in 4 areas (the German Bight, 2 areas along the west coast of Denmark and the Skagerrak) in May during the years 1983 to 1993 . A total of 53302 dab were examined for the presence of the diseases lymphocystis, epidermal papilloma and skin ulcers. The present study describes long-term variations in the prevalence of these 3 diseases. The German Bight and the 2 areas along the west coast of Denmark showed significant similarities in the temporal trend of the diseases investigated with peaks in 1985 and 1988 for both lymphocystis and epidermal papilloma. A similar trend was not observed in the Skagerrak. Skin ulcerations did not reveal any specific temporal trends in any of the 4 areas. The highest prevalence of lymphocystis was observed in the most offshore area along the Danish west coast with a peak value of $14.9 \%$ in 1988; epidermal papilloma in the German Bight showed a peak value of $9.4 \%$ in 1988 and skin ulcers in the Skagerrak a peak of $4.4 \%$ in 1989. Areas in the German Bight and along the west coast of Denmark had suffered from oxygen deficiency in late summer during the years 1981 to 1983 . These events may have been an important factor triggering the outbreak of lymphocystis and epidermal papilloma, as the prevalence of these diseases increased from 1983 until 1985 followed by a decline until 1988. Although it was not possible to establish significant correlations between the oxygen levels at the bottom. and the disease prevalence in the present case, the disease pattern showed evident similarities with formerly described oxygen deficiency-induced outbreaks of lymphocystis and epidermal papilloma in dab in the Kattegat. In 1988, the prevalence of lymphocystis and epidermal papilloma increased significantly without any apparent reason. The disease pattern observed in the Skagerrak differed significantly from the other 3 areas with skin ulcerations being the most prevalent disease. A part of the explanation for this may be that the Skagerrak has not suffered from the same impaired environmental conditions as the other areas.
\end{abstract}

KEY WORDS: Lymphocystis · Epidermal papilloma · Skin ulcers · Dab · Oxygen deficiency · Epidemiology

\section{INTRODUCTION}

The occurrence of diseases in wild fish stocks was already well described at the beginning of this century (Johnstone 1905, 1925), although the prevalence and geographic distribution of the diseases had not yet been determined. However, since the early 1970s, when the close relationship between environmental stress and the outbreak of fish diseases was generally

•E-mail: stig.mellergaard@vetmi.kvl.dk accepted (Wedemeyer 1970, Snieszko 1974), a series of investigations has been conducted into the impact of pollution on disease in natural fish stocks. The first considerations and results of this work on the monitoring of biological effects of marine pollution were summarized by McIntyre \& Pearce (1980).

During the late 1970 s and early 1980 s, studies on diseases in wild fish stocks were carried out in many countries, especially those bordering the North Sea and in the USA (Christensen 1980, Dethlefsen 1980, 1984, Möller 1981, Despres-Patanjo et al. 1982, Deth- 
lefsen \& Watermann 1982, Mellergaard \& Nielsen 1984 1985, 1995, 1996, Vethaak 1991, 1992, 1993, Lindesjöö \& Thulin 1994). However, most of this work consisted of short-term investigations in relatively restricted areas (McArdle et al. 1982, Bucke et al. 1983, Möller 1984, Bucke \& Nicholson 1987, Vethaak et al, 1992).

In order to obtain sufficient data for a more overall assessment of the impact of temporal and spatial variations of environmental parameters on the disease status of fish stocks, long-term disease investigations are needed. Some long-term investigations including ones examining the prevalence and the temporal and spatial trends of fish diseases over wider sea areas have been reported by Dethlefsen et al. (1987) and Dethlefsen (1990), who examined diseases in common dab Limanda limanda in most of the North Sea, by Banning (1987), who conducted disease studies in common dab, plaice Pleuronectes platessa and cod Gadus morhua in the south-eastern North Sea, and by Mellergaard \& Nielsen (1990, 1995, 1996), who carried out disease studies in common dab in Danish coastal zones.

The present work deals with a long-term study of the epidemiology of selected externally visible skin lesions of dab in an area stretching from the German Bight to the Skagerrak. Possible association has been sought between observed temporal and spatial variations in disease rates and environmental parameters that might be of importance as stress factors.

\section{MATERIAL AND METHODS}

Fish sampling. Common dab Limanda limanda L. were sampled annually in May from 1983 to 1992/93 on board the RV 'Dana' using a Nymplex standard fishing trawl, Star model. The trawl was rigged either with 12 " (30 cm) rubber discs or with $10^{\prime \prime}(25 \mathrm{~cm})$ bobbins on the foot-rope, depending on the bottom conditions, and fitted with a foot rope chain. The stretched mesh size in the cod end was $40 \mathrm{~mm}$. Fishing took place at a number of sites in the German Bight and along the west coast of Denmark where trawl tracks were available from commercial fishermen. Standard $1 \mathrm{~h}$ hauls were taken at a speed of 3 knots. One or two hauls were taken at each station. The present work deals with data obtained from a set of stations (see Fig. 1) which are classified into 4 areas based on geographical conditions and on length, weight (condition factor) and age parameters of the fish.

Handling of the sample. The total catch was sorted by species and the dab were subjected to further investigation. A sample of 150 to 250 specimens (a sample size required for the detection of a prevalence of at least 2 with $95 \%$ confidence; Martin et al. 1987) per haul was examined. This number of fish corresponded to 15 to $20 \mathrm{~kg}$. Subsamples were taken at random if the total weight of dab exceeded $20 \mathrm{~kg}$. For all fish examined, the length, weight, sex and health status were registered. After recording the disease, the otoliths from the first 96 fish were removed and stored in small paper bags for ageing later in the laboratory according to standard stock assessment procedures.

Selection of gross lesions. The dab were examined for the presence of the diseases lymphocystis, epidermal hyperplasia/papilloma and skin ulcers using recommended procedures for detection (Anonymous 1989) These diseases have been well described in the literature (Moller \& Anders 1983, Bucke et al. 1996) in terms of their gross appearance and aetiology.

Lymphocystis: The criterion for recording was the presence of more than 1 surface nodule.

Epidermal hyperplasia/papilloma: The criterion for recording was 1 or more lesions larger than $2 \mathrm{~mm}$ in diameter. In the present work, epidermal hyperplasia and papilloma are both designated 'epidermal papilloma'.

Skin ulcerations: The criterion for recording was 1 or more open lesions.

Macroscopic inspection. Prior to external inspection the fish were rinsed with sea water. Both sides of the fish were carefully examined visually and by palpation, and the fins were spread and lifted. The examination took place under a strong light source

In order to obtain the highest degree of precision in the diagnostics of the diseases, only 1 person conducted the registration during the whole period of the investigation. The otoliths were read (enumeration of summer rings) by 2 skilled persons.

Analysis of data. Most of the data analyses were carried out using the public domain software 'Epi-Info' version 6.01 (Dean et al. 1994) and Statistix ${ }^{\otimes}$, version 4.1 (Analytical Software). The strength of association between a factor and a disease is known as the relative risk ( $R R$ ). The $R R$ is calculated as the ratio between the disease rate in an 'exposed' group and the disease rate in an 'unexposed' group. All RR estimations are presented with $95 \%$ confidence intervals.

The RR in an 'exposed' group is significantly different from the RR in an 'unexposed' group if the confidence interval does not encompass the value 1 ( $p<$ $0.05)$. All calculations of $\mathrm{RR}$ were done relative to the 1992 figures for Areas 1 and 3 and to the 1993 figures for Areas 2 and 4, as these figures to a certain extent seem to represent the baseline situation

The statistical tests applied for the data treatment were the nonparametric tests chi-square, MannWhitney rank test and Kruskal-Wallis 1-way ANOVA for non-normally distributed data; and the parametric tests 2-sample t-test and 1-way ANOVA for normally distributed data. 
The condition factor $\left[100 \times\right.$ weight $(\mathrm{g}) \times$ length $\left.^{-3}(\mathrm{~cm})\right]$ was calculated based on the total weight of individual fish (in contrast to gutted weight as recommended in Anonymous 1989).

Oxygen data. Data on the temperature, salinity and oxygen concentrations in the areas represent measurements at the bottom and were obtained from the Environmental Database of the International Council for the Exploration of the Sea (ICES) Hydrographic Service.

\section{RESULTS}

All data presented were sampled at 15 stations distributed along the Danish west coast (Fig. 1). These stations were separated into 4 areas, based on geographical conditions as well as stock characteristics such as length, age and condition factor: a southern zone, designated Area 1, representing the German Bight; 2 central zones, one offshore, Area 2, and one coastal, Area 3; and a northern zone, Area 4, representing the Skagerrak. The mean length, mean age and mean condition factor for dab in the 4 areas are shown in Table 1. The mean length of the dab in the 4 areas differed significantly (1-way ANOVA) ( $p<$ 0.0001 ) and a comparison of means (Tukey) showed that the 4 areas were different from each other. The mean age and the mean condition factor of the dabs differed significantly (Kruskal-Wallis) $(p<0.0001$ ) between the 4 areas and a comparison of means (modified least significant difference test, LSD) showed that all 4 areas differed from each other. In 1993 the sampling was restricted to the Areas 2 and 4.

During the 11 yr of investigation a total of $53302 \mathrm{dab}$ were examined. The distribution of the number of examined dab and dabs affected with lymphocystis, epidermal papillomas and skin ulcers, respectively, over the different areas appears in Table 2.

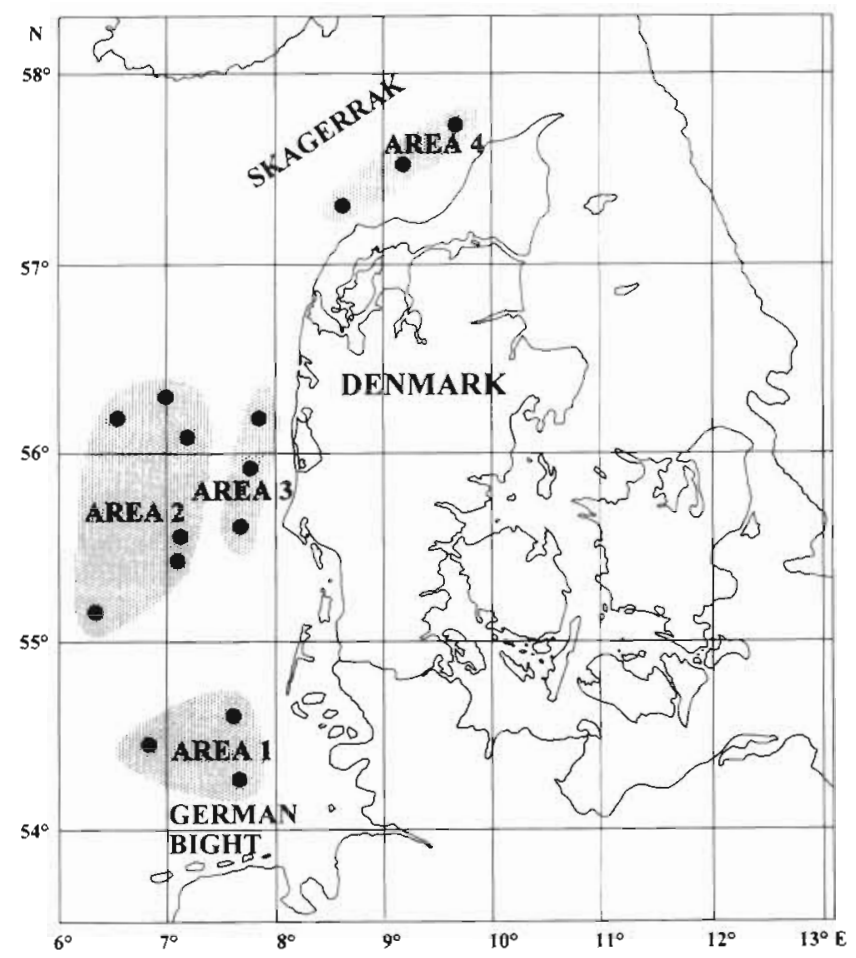

Fig. 1. Station pattern within the 4 areas investigated

Table 1. Limanda limanda. Characteristics used for separation of the 4 areas

\begin{tabular}{|cccc|}
\hline Area & $\begin{array}{c}\text { Mean age } \\
\text { (yr) }\end{array}$ & $\begin{array}{c}\text { Mean length } \\
(\mathrm{cm})\end{array}$ & $\begin{array}{c}\text { Mean condi- } \\
\text { tion factor }\end{array}$ \\
\hline 1 & $3.71 \pm 1.34$ & $17.95 \pm 3.50$ & $0.9380 \pm 0.1170$ \\
2 & $3.59 \pm 1.16$ & $17.44 \pm 3.93$ & $0.9821 \pm 0.4970$ \\
3 & $3.44 \pm 1.11$ & $17.13 \pm 4.28$ & $0.9840 \pm 0.4763$ \\
4 & $2.80 \pm 0.95$ & $17.63 \pm 4.21$ & $1.0335 \pm 0.2417$ \\
\hline
\end{tabular}

Table 2. Limanda limanda. Total number of dab examined and number of fish affected with lymphocystis, epidermal papilioma and skin ulcers separated by area and year. -: no data

\begin{tabular}{|c|c|c|c|c|c|c|c|c|c|c|c|c|c|c|c|c|}
\hline \multirow[t]{2}{*}{ Year } & \multicolumn{4}{|c|}{ Area 1} & \multicolumn{4}{|c|}{ Area 2} & \multicolumn{4}{|c|}{ Area 3} & \multicolumn{4}{|c|}{ Area 4} \\
\hline & $\mathrm{n}$ & $\begin{array}{l}\text { Lym- } \\
\text { phocy. }\end{array}$ & $\begin{array}{l}\text { Epid. } \\
\text { papill. }\end{array}$ & $\begin{array}{l}\text { Skin } \\
\text { ulcer }\end{array}$ & $\mathrm{n}$ & $\begin{array}{l}\text { Lym- } \\
\text { phocy. }\end{array}$ & $\begin{array}{l}\text { Epid. } \\
\text { papill. }\end{array}$ & $\begin{array}{l}\text { Skin } \\
\text { ulcer }\end{array}$ & $n$ & $\begin{array}{l}\text { Lym- } \\
\text { phocy. }\end{array}$ & $\begin{array}{l}\text { Epid. } \\
\text { papill. }\end{array}$ & $\begin{array}{l}\text { Skin } \\
\text { ulcer }\end{array}$ & $\mathrm{n}$ & $\begin{array}{l}\text { Lym- } \\
\text { phocy. }\end{array}$ & $\begin{array}{l}\text { Epid. } \\
\text { papill. }\end{array}$ & $\begin{array}{l}\text { Skin } \\
\text { ulcer }\end{array}$ \\
\hline 1983 & 907 & 80 & 13 & 17 & 657 & 61 & 6 & 7 & 460 & 14 & 4 & 10 & 693 & 5 & 1 & 13 \\
\hline 1984 & 2925 & 294 & 170 & 27 & 5054 & 452 & 120 & 33 & 698 & 50 & 17 & 8 & 408 & 4 & 1 & 3 \\
\hline 1985 & 1628 & 205 & 111 & 16 & 1529 & 210 & 55 & 16 & 727 & 47 & 22 & 4 & 981 & 9 & 3 & 2 \\
\hline 1986 & 1185 & 95 & 98 & 13 & 2038 & 131 & 69 & 12 & 831 & 23 & 21 & 3 & 759 & 3 & 0 & 2 \\
\hline 1987 & 850 & 66 & 56 & 7 & 1947 & 89 & 34 & 17 & 504 & 16 & 8 & 2 & 487 & 1 & 1 & 1 \\
\hline 1988 & 913 & 117 & 86 & 7 & 1612 & 240 & 96 & 16 & 734 & 100 & 58 & 5 & 785 & 9 & 1 & 5 \\
\hline 1989 & 1075 & 83 & 36 & 11 & 2238 & 277 & 74 & 19 & 1554 & 115 & 60 & 27 & 159 & 0 & 2 & 7 \\
\hline 1990 & 1159 & 63 & 29 & 22 & 1757 & 194 & 35 & 11 & 1239 & 102 & 28 & 11 & 368 & 11 & 2 & 14 \\
\hline 1991 & 1184 & 87 & 58 & 8 & 2078 & 159 & 53 & 10 & 891 & 59 & 27 & 10 & 931 & 9 & 2 & 7 \\
\hline 1992 & 1329 & 60 & 73 & 7 & 2639 & 161 & 61 & 15 & 1748 & 57 & 42 & 7 & 1006 & 14 & 4 & 4 \\
\hline 1993 & - & - & - & - & 1461 & 103 & 37 & 23 & - & - & - & - & 1187 & 5 & 2 & 22 \\
\hline Total & 13153 & 1150 & 730 & 134 & 23002 & 2076 & 640 & 179 & 9384 & 583 & 287 & 87 & 7763 & 70 & 19 & 80 \\
\hline
\end{tabular}




\section{Disease examination}

\section{Lymphocystis}

In Area 1, the prevalence of lymphocystis varied from $12.8 \%$ as peak values to $4.5 \%$ as the lowest level. The temporal pattern showed an increase in the prevalence from 1983 to 1985 followed by a decrease in the following 2 yr then a sudden decrease in 1988 followed by a further decline in the succeeding years (Fig. 2). The RR of contracting lymphocystis was significantly higher in the whole period of investigation compared to 1992, except for 1990. Peaks were observed in 1985 and 1988, respectively (Fig. 3). The RR in 1990 was at the same level as in 1992.

In Area 2, the prevalence of lymphocystis ranged from 4.6 to $14.9 \%$ (Fig. 2). A similar pattern of annual variation in the prevalence of lymphocystis was observed as in Area 1 with increasing prevalence occurring from 1983 to 1985 followed by a decrease during 1986 and 1987, a 3 -fold increase from 4.6 to $14.9 \%$ from 1987 to 1988 with a gradual decline the following years. The RR was significantly higher in 1984 and 1985 and from 1988 to 1990 while significantly lower in 1987, relative to 1993 (Fig. 3). The RR in 1983, 1986 and in 1991 and 1992 was at the same level as in 1993.

Area 3 revealed an increase in the prevalence of lymphocystis from $3.0 \%$ in 1983 to $7.2 \%$ in 1984 followed by a decrease to $3.2 \%$ in 1987 (Fig. 2). In 1988, an increase to $13.6 \%$ was observed followed by a decline as observed in the 2 previous areas. The RR of contracting lymphocystis was significantly greater from 1984 to 1985 and during the period from 1988 to 1991 relative to 1992 (Fig. 3). In 1983, 1986, and 1987, the RR did not show any significant differences compared to 1992.

In contrast to Areas 1, 2 and 3, the prevalence of lymphocystis in Area 4 varied from 0\% in 1989 to $3 \%$ in 1990 without any specific trends (Fig. 2). Most years it was at a level of approximately $1 \%$. The RR of contracting lymphocystis in Area 4 was at the same level during the $11 \mathrm{yr}$ of investigation except for 1990 and 1992, when it increased significantly relative to 1993 (Fig. 3). Because the number of affected fish was limited, the confidence levels of the RR were very broad.

Lymphocystis appeared evenly distributed among the sexes except in Area 3, where females had a significantly lower risk of contracting the disease (0.71 times) than males (Table 3 ).
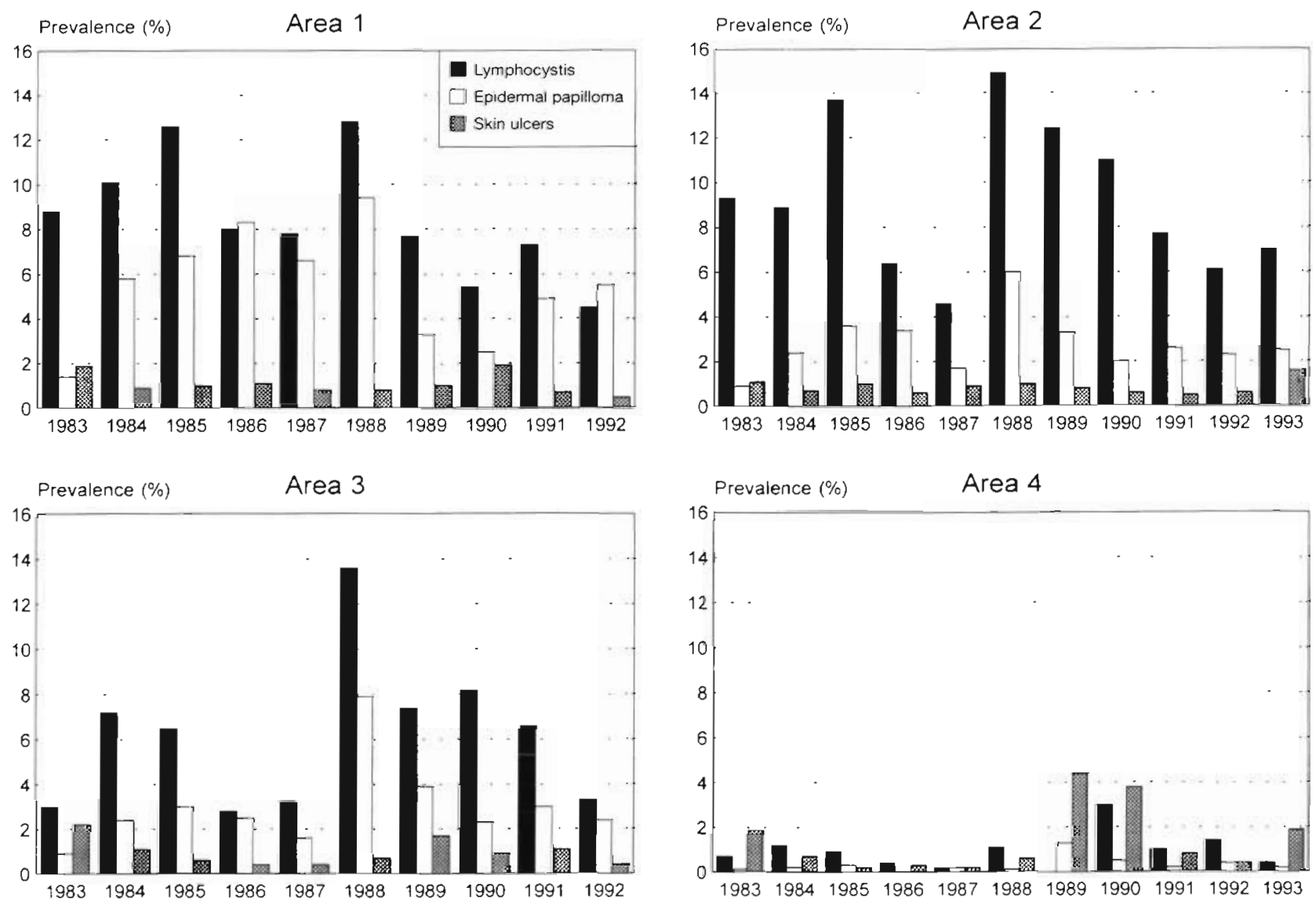

Fig. 2. Limanda limanda. Prevalence rates of lymphocystis, epidermal papilloma and skin ulcers at the 4 areas investigated 

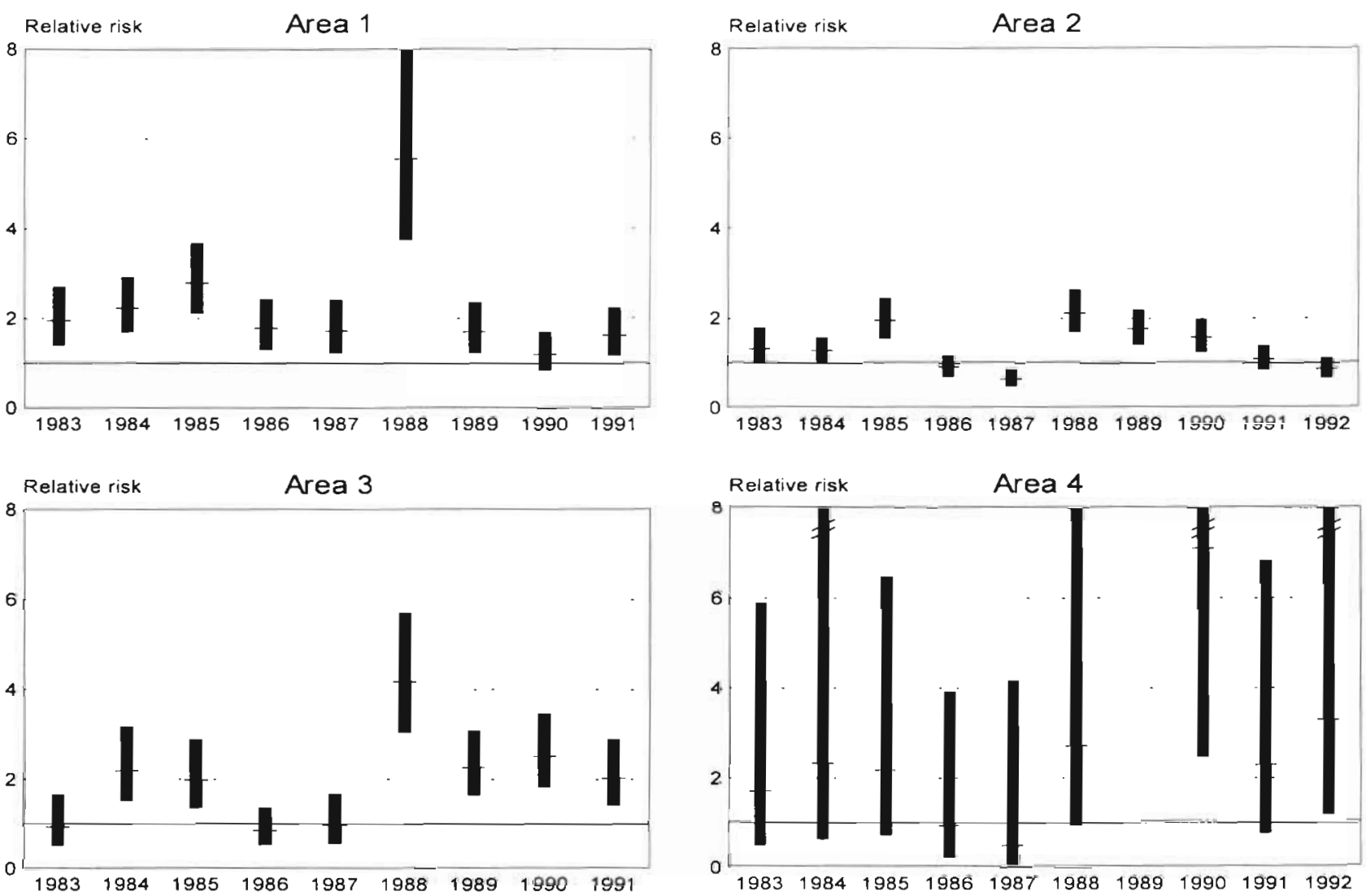

Fig. 3. Limanda limanda. Relative risk of contracting lymphocystis at the 4 areas presented with $95 \%$ confidence intervals (bar). Where bars do not cross 1 (horizontal line), values are significantly different from the 1992/93 values

Lymphocystis did not affect the mean condition factor of the dab in the different areas except in Area 1, where the condition factor of lymphocystis-affected fish was significantly higher compared to the unaffected fish (Table 4). In general, the condition factor of lymphocystis-affected fish was higher than for the unaffected.

The mean age was found to be significantly higher for lymphocystis-affected than for unaffected fish in all 4 areas investigated (Table 4 ).

\section{Epidermal papilloma}

In Area 1, the prevalence of epidermal papilloma ranged from 1.4 to $9.4 \%$ (Fig. 2). It increased from $1.4 \%$ in 1983 to $8.3 \%$ in 1986 with a minor decrease in 1987. Prevalence increased to $9.4 \%$ in 1988 followed by a rapid decline from 1989 to 1990 to $2.5 \%$. In 1991 and 1992 prevalence increased to approximately $5 \%$. Compared to 1992 , the RR was significantly higher in 1986 and in 1988 and significantly lower in 1983, 1989 and 1990 (Fig. 4). The other years were at the same level as 1992 .
In Area 2 the prevalence of epidermal papilloma was at its lowest level, $0.9 \%$, in 1983 peaking at $6 \%$ in 1988 (Fig. 2). An increase was observed from 1983 to 1985 followed by a decrease to $1.7 \%$ in 1987 . After having peaked with a prevalence of $6 \%$ in 1988, a gradual decrease to approximately $2 \%$ was observed the following years. Except for 1983, when the RR was significantly reduced relative to 1992 and for 1988, when the RR was significantly increased, the RR was at the same level as in 1992 (Fig. 4).

Table 3. Limanda limanda. Sexual difference in the risk of contracting the 3 diseases in the 4 areas (female relative to male). $p$-values given for significant differences

\begin{tabular}{|lcccc|}
\hline & Area 1 & Area 2 & Area 3 & Area 4 \\
\hline $\begin{array}{l}\text { Lympho- } \\
\text { cystis }\end{array}$ & 0.93 & 1.0 & $\begin{array}{c}0.71 \\
(\mathrm{p}<0.001)\end{array}$ & 0.88 \\
$\begin{array}{l}\text { Epidermal } \\
\text { papilloma } \\
\text { Skin ulcer }\end{array}$ & $\begin{array}{c}1.47 \\
\mathrm{p}<0.001)\end{array}$ & $\begin{array}{c}1.76 \\
(\mathrm{p}<0.001)\end{array}$ & 1.22 & 1.54 \\
& & $\begin{array}{c}1.86 \\
(\mathrm{p}<0.001)\end{array}$ & 0.8 & $\begin{array}{c}2.24 \\
(\mathrm{p}<0.05)\end{array}$ \\
\hline
\end{tabular}


Table 4. Limanda limanda. Mean condition factor and age of unaffected and lymphocystis, epidermal papilloma and skin ulcer affected dab for the 4 areas. p-values given for significant difference (Mann-Whitney rank sum)

\begin{tabular}{|c|c|c|c|c|c|}
\hline & & Area 1 & Area 2 & Area 3 & Area 4 \\
\hline \multicolumn{6}{|l|}{ Lymphocystis } \\
\hline Condition factor & $\begin{array}{l}\text { Unaffected } \\
\text { Lymphocystis }\end{array}$ & $\begin{array}{c}0.9346 \\
0.9432 \\
(\mathrm{p}<0.05)\end{array}$ & $\begin{array}{l}0.9692 \\
0.9738\end{array}$ & $\begin{array}{l}0.9583 \\
0.9590\end{array}$ & $\begin{array}{l}1.0214 \\
1.0189\end{array}$ \\
\hline Age & $\begin{array}{l}\text { Unaffected } \\
\text { Lymphocystis }\end{array}$ & $\begin{array}{c}3.66 \\
4.19 \\
(p<0.0001)\end{array}$ & $\begin{array}{c}3.52 \\
4.17 \\
(p<0.0001)\end{array}$ & $\begin{array}{c}3.38 \\
4.12 \\
(p<0.0001)\end{array}$ & $\begin{array}{c}2.79 \\
3.42 \\
(p<0.0005)\end{array}$ \\
\hline \multicolumn{6}{|c|}{ Epidermal papilloma } \\
\hline Condition factor & $\begin{array}{l}\text { Unaffected } \\
\text { Epidermal papilloma }\end{array}$ & $\begin{array}{l}0.9352 \\
0.9383\end{array}$ & $\begin{array}{l}0.9693 \\
0.9815\end{array}$ & $\begin{array}{l}0.9580 \\
0.9662\end{array}$ & $\begin{array}{l}1.0213 \\
1.0296\end{array}$ \\
\hline Age & $\begin{array}{l}\text { Unaffected } \\
\text { Epidermal papilloma }\end{array}$ & $\begin{array}{c}3.69 \\
4.07 \\
(p<0.0001)\end{array}$ & $\begin{array}{c}3.57 \\
4.27 \\
(p<0.0001)\end{array}$ & $\begin{array}{c}3.41 \\
4.10 \\
(p<0.0001)\end{array}$ & $\begin{array}{c}2.80 \\
3.83 \\
(p<0.001)\end{array}$ \\
\hline \multicolumn{6}{|l|}{ Skin ulcers } \\
\hline Condition factor & $\begin{array}{l}\text { Unaffected } \\
\text { Skin ulcer }\end{array}$ & $\begin{array}{l}0.9356 \\
0.9225\end{array}$ & $\begin{array}{l}0.9699 \\
0.9520\end{array}$ & $\begin{array}{c}0.9589 \\
0.8929 \\
(p<0.001)\end{array}$ & $\begin{array}{c}1.0218 \\
0.9835 \\
(\mathrm{p}<0.05)\end{array}$ \\
\hline Age & $\begin{array}{l}\text { Unaffected } \\
\text { Skin ulcer }\end{array}$ & $\begin{array}{c}3.71 \\
4.18 \\
(p<0.0001)\end{array}$ & $\begin{array}{c}3.58 \\
4.18 \\
(p<0.0001)\end{array}$ & $\begin{array}{c}3.43 \\
4.00 \\
(p<0.01)\end{array}$ & $\begin{array}{c}2.79 \\
3.28 \\
(p<0.0005)\end{array}$ \\
\hline
\end{tabular}
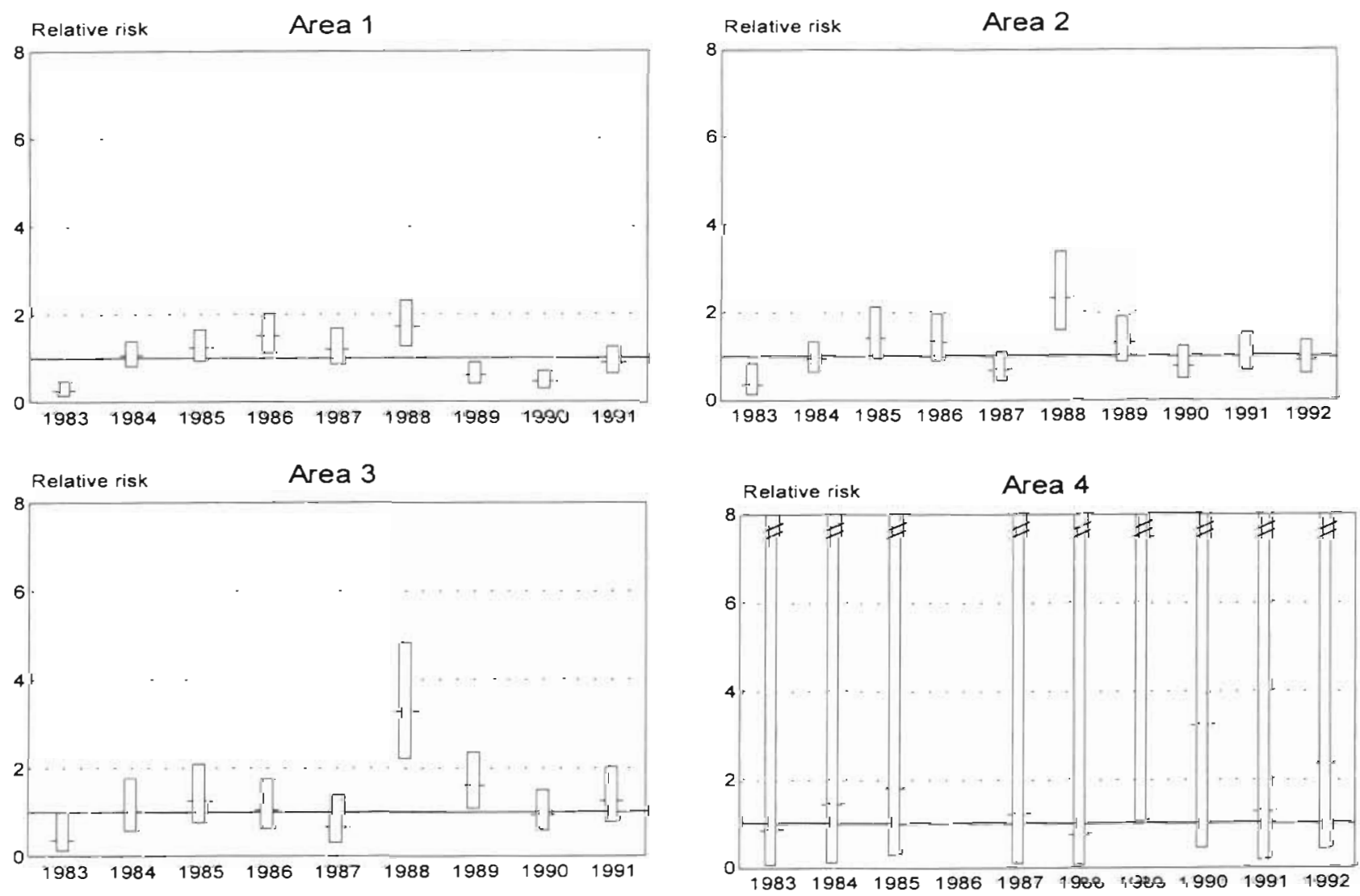

Fig. 4. Limanda limanda. Relative risk of contracting epidermal papilloma at the 4 areas presented with $95 \%$ confidence intervals (bar). Where bars do not cross 1 (horizontal line), values are significantly different from the 1992/93 values 
The temporal variation pattern of the prevalence of epidermal papilloma in Area 3 was very similar to that of Area 2 (Fig. 2). Prevalence was $0.9 \%$ in 1983 and showed an increase until 1985. A decrease to $1.6 \%$ was observed in 1987 followed by a increase to $7.9 \%$ in 1988. Beginning in 1989 the prevalence showed a decline to about $2 \%$. The RR was at the same overall level as in 1993 during the whole period of investigation except in 1988 and 1989, which showed a significantly increased risk (Fig. 4).

In Area 4, the prevalence of epidermal papilloma was within the range of 0 to $1.3 \%$ and did not show any significant pattern (Fig. 2). Except for 1989, when the RR was significantly higher relative to 1993, the RR of contracting epidermal papilloma was at the same level the other years but revealed broard confidence levels due to the restricted number of infected specimens (Fig. 4).

In Areas 1 and 2 females had a significantly higher risk of contracting epidermal papilloma than males. In Areas 3 and 4 females also had a higher but not sig- nificantly different risk of contracting the disease compared to males (Table 3 ).

In general, epidermal papilloma-affected fish had a higher condition factor than unaffected fish but the difference was not statistically significant (Table 4).

As for lymphocystis the mean age of epidermal papilloma-affected fish was significantly higher compared to the unaffected population in all areas (Table 4).

\section{Skin ulcerations}

The prevalence of skin ulcers in Area 1 varied from $0.5 \%$ as the lowest to $1.9 \%$ as the peak value with a mean level of approximately $1 \%$ (Fig. 2). It did not show any specific trends. The RR was significantly higher in 1983 and 1990 relative to 1992 while the RR in the other years was at the same level as in 1992 (Fig. 5).

In Area 2, the prevalence of skin ulcers was around the same level as in Area 1, 0.5 to $1.6 \%$, with a mean
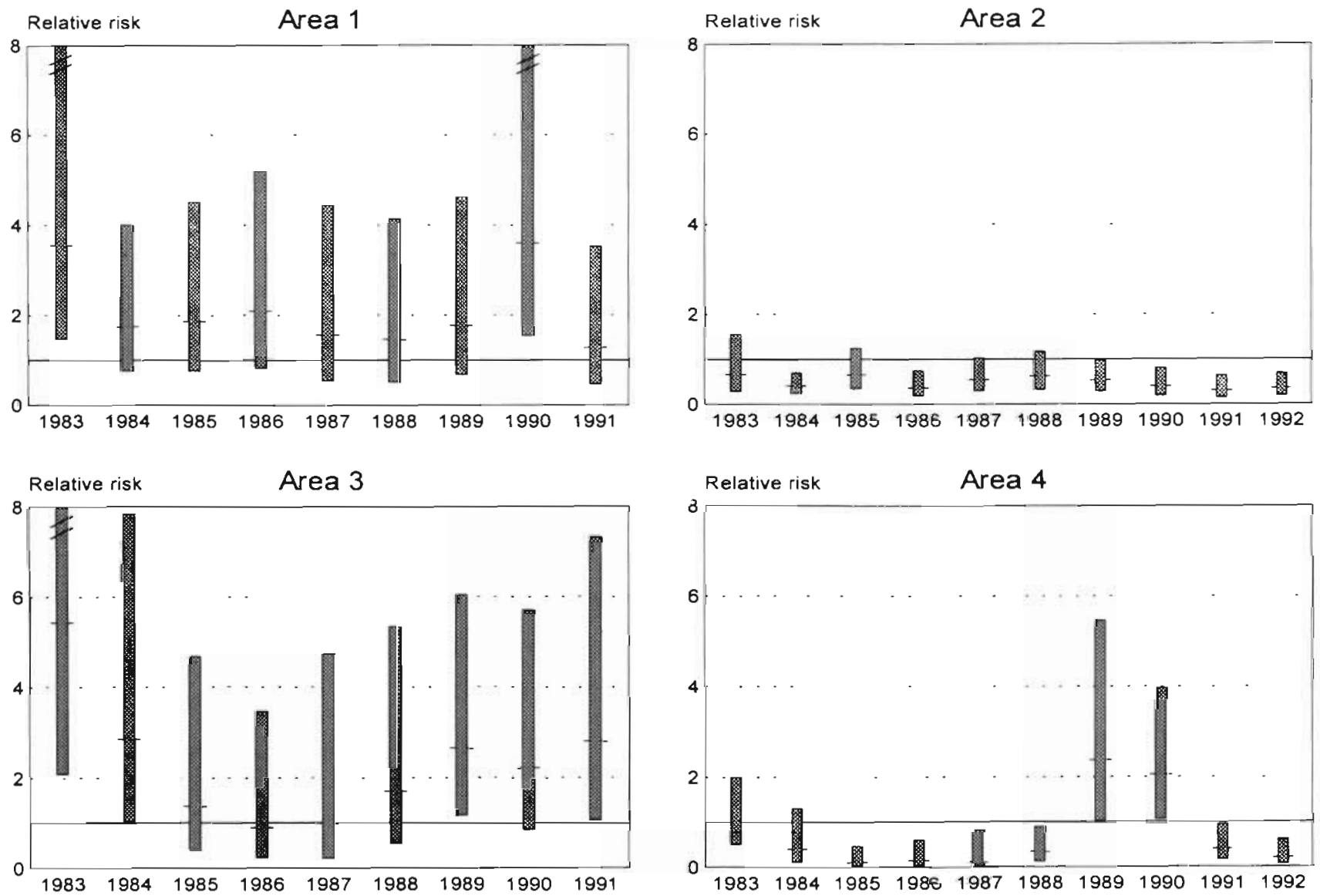

Fig. 5. Limanda limanda. Relative risk of contracting skin ulcers at the 4 areas presented with $95 \%$ confidence intervals (bar) Where bars do not cross 1 (horizontal line), values are significantly different from the 1992/93 values 
level just below 1\% (Fig. 2). The RR did not differ significantly compared to 1993 (Fig. 5).

Area 3 reflected the level of prevalence observed in Areas 1 and 2, being within the range of 0.4 to $2.2 \%$ with minor annual variations without any pattern. The RR was significantly higher in 1983, 1984, 1989 and in 1991 relative to 1992 while it was at a level similar to that of 1992 in the other years.

In contrast to the previous 3 areas, skin ulcerations seemed to be the most prevalent disease in Area 4. Apart from 1983, which showed a prevalence of $1.9 \%$, the level was within the range of 0.2 to $0.7 \%$ in the period 1984 to 1988 (Fig. 2). The prevalence of skin ulcers increased to $4.4 \%$ in 1989 and $3.8 \%$ in 1990 followed by a decrease to a level of approximately $1 \%$ in the period 1991 to 1992 and then by an increase in 1993. During the periods from 1985 to 1988 and from 1991 to 1992 the RR was significantly lower as compared to 1993. A significant increase was observed in 1989 and 1990 while in 1983 and 1984 RR was at the same level as observed in 1993 (Fig. 5).

Female dab had a significantly higher risk of contracting skin ulcers in Areas 2 and 4 (1.9 and 2.2 times, respectively) while the risk was slightly lower in Areas 1 and 3 (Table 3).

Skin ulcerations had a negative effect on the condition of the fish. The difference in the condition factor between ulcerated dab and unaffected fish was statistically significant in Areas 3 and 4 (Table 4 ).

The mean age of ulcerated dab was significantly higher than in unaffected fish in all areas (Table 4).

\section{Correlations}

\section{Diseases}

The prevalence of lymphocystis and epidermal papilloma showed a positive but not statistically significant correlation $(0.49<\mathrm{r}<0.56,0.12<\mathrm{p}<0.09)$ (Spearman rank correlation test) for Areas 1, 2 and 3 for the whole period of investigation. The other combinations of diseases in the different areas did not show any clear correlation pattern.

\section{Diseases and stock density}

The mean stock density calculated on the basis of the area fished during $1 \mathrm{~h}$ of trawl tow was $19,7,6$ and 2 dab per $1000 \mathrm{~m}^{2}$ in Areas 1, 2, 3 and 4, respectively. The stock density expressed as the catch per unit effort (number of dab per h of trawl time) showed marked annual variation (Table 5) with Area 1 showing the highest trend and Area 4 the lowest. The Spearman
Table 5. Limanda Limanda. Catch per unit effort (no. of fish ${ }^{-1}$ ) for the 4 areas investigated during the period 1983 to 1993. -: no data

\begin{tabular}{|ccccc|}
\hline Year & Area 1 & Area 2 & Area 3 & Area 4 \\
\hline 1983 & 226 & 379 & 987 & 139 \\
1984 & 7327 & 681 & 380 & 73 \\
1985 & 1403 & 917 & 242 & 164 \\
1986 & 609 & 1334 & 280 & 132 \\
1987 & 1007 & 1132 & 1082 & 84 \\
1988 & 464 & 410 & 1007 & 160 \\
1989 & 5753 & 1794 & 1636 & 34 \\
1990 & 2903 & 1014 & 531 & 145 \\
1991 & 3326 & 1119 & 1283 & 617 \\
1992 & 2370 & 987 & 709 & 704 \\
1993 & - & 658 & - & 553 \\
Mean & 2539 & 948 & 814 & 255 \\
\hline
\end{tabular}

rank correlation test did not show any statistically significant correlation between the stock density and the prevalence of the different diseases except for skin ulcers in Area 2, where a significant negative correlation was found $(r=-0.6207, p<0.05)$

\section{Diseases and condition factor}

A statistically significant correlation (Spearman rank correlation test) between the prevalence of the different diseases and the mean condition factor (Table 6) was found for lymphocystis in Area 3 ( $r=-0.8788$, $p<0.001)$ and in Area $4(r=-0.6119, p<0.05)$ and for epidermal papilloma in Area $3(\mathrm{r}=-0.6525, \mathrm{p}<0.05)$.

\section{Diseases and oxygen deficiency}

Test for correlations between the diseases and oxygen deficiency was conducted by comparing the prevalence of different diseases in one year with the

Table 6. Limanda limanda. Mean condition factor for dab in the 4 areas investigated during the period 1983 to 1993. -: no data

\begin{tabular}{|ccccc|}
\hline Year & Area 1 & Area 2 & Area 3 & Area 4 \\
\hline 1983 & 0.939 & 1.018 & 1.015 & 1.126 \\
1984 & 0.928 & 0.990 & 0.959 & 0.990 \\
1985 & 0.926 & 1.001 & 0.971 & 1.035 \\
1986 & 0.973 & 0.997 & 1.031 & 0.991 \\
1987 & 0.964 & 0.980 & 1.008 & 1.041 \\
1988 & 0.921 & 0.872 & 0.952 & 1.034 \\
1989 & 0.926 & 0.895 & 0.889 & 1.075 \\
1990 & 0.959 & 1.034 & 0.990 & 0.980 \\
1991 & 0.934 & 0.944 & 1.000 & 1.031 \\
1992 & 0.914 & 0.970 & 1.006 & 0.990 \\
1993 & - & 1.001 & - & 1.020 \\
& & & & \\
\hline
\end{tabular}


Table 7. Oxygen level ( $\mathrm{mI} \mathrm{l}^{-1}$ ) (mean/minimum) at the bottom in August for 4 areas investigated during the period 1982 to 1990

\begin{tabular}{|ccccc|}
\hline Year & Area 1 & Area 2 & Area 3 & Area 4 \\
\hline 1982 & $3.39 / 1.66$ & $3.15 / 2.14$ & $2.91 / 1.22$ & $5.13 / 5.00$ \\
1983 & $2.34 / 1.39$ & $2.47 / 0.43$ & $3.44 / 1.13$ & $4.95 / 3.88$ \\
1984 & $3.88 / 3.41$ & $3.81 / 2.86$ & $5.20 / 4.45$ & $5.81 / 5.31$ \\
1985 & $5.54 / 5.00$ & $5.43 / 4.44$ & $5.61 / 5.22$ & $5.38 / 4.61$ \\
1986 & $4.75 / 3.33$ & $3.78 / 1.37$ & $4.95 / 4.13$ & $5.38 / 4.94$ \\
1987 & $5.07 / 4.35$ & $4.96 / 3.85$ & $5.91 / 5.59$ & $5.44 / 4.87$ \\
1988 & $5.25 / 4.77$ & $5.41 / 3.09$ & $5.18 / 4.91$ & $5.46 / 4.16$ \\
1989 & $5.46 / 4.92$ & $3.90 / 2.08$ & $5.85 / 5.26$ & $5.28 / 4.56$ \\
1990 & $5.29 / 5.08$ & $4.73 / 4.35$ & $5.60 / 4.98$ & $6.26 / 5.05$ \\
& & & & \\
\hline
\end{tabular}

mean and minimum oxygen levels measured in August (Table 7) the previous year, as it was hypothesised that low oxygen levels in the autumn might affect the disease level the following year. The Spearman rank correlation test did not reveal any clear correlation pattern between the prevalence of the diseases and the mean and minimum oxygen levels measured in August and September the previous year.

\section{Diseases and water temperature}

The tests for correlations between diseases and bottom water temperature were conducted by comparing the prevalence of the different diseases in one year with the mean temperature of the 12 mo prior to the investigation (i.e. from May to April) (Table 8). A statistical significant negative correlation (Spearman rank correlation test) was found between temperature and epidermal papilloma in Area $1(\mathrm{r}=-0.7333, \mathrm{p}<$ $0.05)$ and in Area $2(r=-0.7091, p<0.05)$. Skin ulcerations were found significantly positively correlated to temperature in Area $4(\mathrm{r}=0.6879, \mathrm{p}<0.05)$. No other associations between diseases and temperature were observed.

\section{Diseases and salinity}

The correlations between salinity and diseases were carried out by comparing the prevalence of the different diseases with the mean salinity of the year prior to the disease investigation (i.e. from May to April) (Table 8). The prevalence of lymphocystis and salinity was significantly negatively correlated at Area 1 ( $r=-0.6970, p<0.05)$. Epidermal papilloma and skin ulcers did not show any distinct correlation pattern nor did lymphocystis in the other areas.

\section{DISCUSSION}

The present study describes long-term variations in the prevalence of the diseases lymphocystis, epidermal papilloma and skin ulcers in dab in 4 different areas in the eastern North Sea and the Skagerrak. Areas 1, 2 and 3 showed significant similarities in the temporal disease pattern with peaks in 1985 and 1988 for lymphocystis and epidermal papilloma, although based on different disease levels. Dethlefsen (1990) reported similar temporal trends from the German Bight for lymphocystis and epidermal papilloma. A similar pattern was not observed in Area 4, the Skagerrak. Skin ulcerations did not reveal any kind of temporal trends in any of the 4 areas and this observation coincides with the trends reported from the German Bight (Dethlefsen 1990). The highest prevalences for lymphocystis and epidermal papilloma were observed in Area 1 (German Bight) and in Area 2 (off the west coast of Denmarkj and for skin ulcers in Area 4 (Skagerrak).

Table 8. Annual mean salinity $(\%)$ and temperature $\left({ }^{\circ} \mathrm{C}\right)$ for the 4 areas investigated during the period May to April $1982 / 83$ to 1992/93. -: no data

\begin{tabular}{|c|c|c|c|c|c|c|c|c|}
\hline \multirow[t]{2}{*}{ Year } & \multicolumn{2}{|c|}{ Area 1} & \multicolumn{2}{|c|}{ Area 2} & \multicolumn{2}{|c|}{ Area 3} & \multicolumn{2}{|c|}{ Area 4} \\
\hline & Salinity & Temp. & Salinity & Temp. & Salinity & Temp. & Salinity & Temp. \\
\hline $1982 / 83$ & 32.2 & 10.3 & 34.1 & 9.1 & 33.2 & 9.0 & 33.9 & 8.6 \\
\hline $1983 / 84$ & 35.6 & 9.6 & 34.1 & 8.9 & 32.8 & 9.7 & 34.2 & 8.5 \\
\hline $1984 / 85$ & 33.0 & 8.0 & 33.9 & 8.1 & 33.1 & 8.1 & 34.2 & 8.1 \\
\hline $1985 / 86$ & 32.6 & 8.8 & 33.5 & 8.1 & 32.9 & 9.3 & 34.6 & 8.3 \\
\hline $1986 / 87$ & 33.1 & 8.8 & 33.9 & 8.6 & 32.9 & 8.8 & 35.2 & 8.0 \\
\hline $1987 / 88$ & 32.2 & 9.3 & 33.7 & 8.3 & 31.7 & 7.9 & 34.0 & 8.4 \\
\hline $1988 / 89$ & 32.2 & 9.4 & 34.1 & 8.8 & 32.8 & 9.7 & 34.0 & 8.9 \\
\hline $1989 / 90$ & 33.4 & 9.6 & 34.3 & 8.9 & 33.3 & 9.7 & 34.4 & 8.8 \\
\hline $1990 / 91$ & 33.1 & 9.5 & 34.6 & 8.7 & 33.8 & 9.6 & 34.6 & 8.9 \\
\hline $1991 / 92$ & 33.4 & - & 34.6 & 8.5 & 33.4 & - & 34.6 & 8.8 \\
\hline $1992 / 93$ & 33.8 & - & 34.7 & - & 34.0 & - & 34.7 & 8.1 \\
\hline
\end{tabular}


Similar temporal parallelisms between the diseases lymphocystis and epidermal papilloma have been described before from the German Bight and the Dogger Bank (Dethlefsen 1990) and from the Kattegat (Mellergaard \& Nielsen 1995), where statistically significant correlation was found between the 2 diseases. In the present study, these diseases were also found positively correlated in the Areas 1,2 and 3 but this correlation was not statistically significant.

The westernmost part of Area 2 suffered seriously from oxygen deficiency in September 1981 (Dyer et al. 1983) and in August and September 1982 and 1983 most of Areas 1, 2 and 3 were hit by oxygen depletion (Dethlefsen \& Westernhagen 1983). It is likely that oxygen deficiency may be one of the provoking factors for fish diseases in these areas. The hypothesis that oxygen depletion might be involved as a stress factor in the outbreak of lymphocystis and epidermal papilloma in the eastern North Sea was put forward by Mellergaard \& Nielsen (1987), whose observations confirmed that in the Kattegat oxygen deficiency was an important factor in provoking the outbreak of these diseases (Mellergaard \& Nielsen 1995). Dethlefsen (1990) found that low oxygen levels may be one of the stress factors contributing to the outbreak of lymphocystis and epidermal papilloma in the German Bight. It has not been possible to establish significant correlations between lymphocystis and epidermal papilloma and oxygen deficiency in the present material as were demonstrated for the Kattegat (Mellergaard \& Nielsen 1995), probably due to the lack of baseline prevalence data for the areas (i.e. before the oxygen deficiency occurred). However, a comparison of the development of the prevalence pattern of lymphocystis and epidermal papilloma in the period 1983 to 1987 for the Areas 1 to 3 with the observations from the Kattegat (Mellergaard \& Nielsen 1995) reveals evident similarities that may suggest that oxygen deficiency may be involved in the disease outbreak. Area 3 was situated in the perifery of the area affected by oxygen depletion in 1982 and 1983. This may explain why Area 3 showed a lower prevalence level of lymphocystis and epidermal papilloma in the period 1983 to 1987 than observed in Areas 1 and 2 .

Temperature is another stressor that might be involved in disease outbreaks. The stress effect of temperature is commonly associated with sudden changes (Strange et al. 1977, Larsen \& Mellergaard 1981) rather than long-term fluctuations. Temperature data from the North Sea area are not registered on a regular basis, so sudden changes will not be registered. Therefore, the observed significant negative correlation between epidermal papilloma and the mean temperature 1 yr prior to the investigation in Areas 1 and 2 is likely to be a coincidence, as a similar response should be expected for the other viral disease, lymphocystis, which appeared to be positively correlated with epidermal papilloma. However, temperature should not be excluded as a contributing stress factor even though its effect cannot be quantified in the present study design. On the contrary, the significant positive correlation between temperature and skin ulcerations is biologically plausible, as high temperature over longer periods improve the conditions for the bacteria affecting the ulcerations.

Salinity changes may also act as a stressor provoking the outbreak of fish diseases. Such events have been described from fish living in the tidal zone in river estuaries (Möller 1981, 1984, 1990) where salinity fluctuations in the range of 4 to $8 \%$ were observed twice a day. Salinity fluctuations in that range are not observed in open sea areas. As in the case of temperature data, salinity data from the North Sea are not registered on a regular basis. Therefore, it is not likely that correlations between mean salinity on an annual basis and diseases will give a true picture of the involvement of salinity as a contributing factor to environmental stress, and the observed positive correlation between salinity and lymphocystis may be accidental.

The significant increase in the relative risk of contracting both lymphocystis and epidermal papilloma observed in 1988 cannot be explained either by oxygen deficiency or by significant changes in the water temperature or salinity. Furthermore, it is unlikely that changes in the virulence of the infectious agents of both diseases would take place at the same time. However, one or more unknown factors must have increased the susceptibility of dab to these 2 viral diseases in the eastern part of the North Sea. The phenomenon seemed to be localized to this area, as Dethlefsen (1990) demonstrated an increase in the prevalence of lymphocystis and epidermal papilloma in the German Bight in 1988 but not in the Dogger Bank area, while our data from the Skagerrak (Area 4) similarly did not reveal significant changes in the disease rates that particular year.

For Area 1 (German Bight) the dumping of waste from titanium dioxide production may be considered an additional factor which might elevate the prevalence of lymphocystis and epidermal papilloma and skin ulcers (Dethlefsen et al. 1987). Larsson et al. (1980) showed that industrial effluent from titanium dioxide production caused significant disturbances in the electrolyte balance and in carbohydrate metabolism and changes in the blood parameters of flounder Platichthys flesus. Such changes may be stressful and lead to increased susceptibility to diseases. Dethlefsen et al. (1987) demonstrated elevated rates of lymphocystis and epidermal papilloma in the dumping areas 
within the German Bight and similar observations have been made in titanium dioxide waste dumping areas along the Dutch coast (Vethaak 1991).

A common feature for the Areas 1,2 and 3 was that skin ulcerations did not show similar temporal fluctuations as observed for lymphocystis and epidermal papilloma. Similar observations were made in the Kattegat (Mellergaard \& Nielsen 1995), where the relative risks of contracting both lymphocystis and epidermal papilloma were affected by oxygen deficiency while skin ulcerations seemed unaffected.

In Area 4 (Skagerrak) the 3 diseases investigated did not display similar temporal variations in prevalence similar to those observed in Areas 1,2 and 3. The significant increase in the relative risk of contracting lymphocystis in 1990 may be accidental. The increase in the prevalence of skin ulcers in 1989 and 1990 might be due to increased fishing intensity in the area as a part of the fishing fleet operating in the Kattegat area turned to the Skagerrak because the environmental conditions had caused a serious reduction in the abundance of fish species of commercial interest.

The stock density was highest in Area 1 (German Bight) with mean catches of 2539 dab per h trawling and was lowest in Area 4 (Skagerrak) with 255 dab per h. It was not possible to establish any clear correlation between the prevalence of the diseases and stock density except for skin ulcers in Area 2, which were found to be significantly negatively correlated with stock density. Such a correlation is unlikely to be biologically plausible, as the transmission of diseases should be facilitated by higher stock density. Although positive correlations between disease prevalence and stock density could not be established, it is possible that the differences in stock density between the Areas 1, 2 and 3 and Area 4 are a factor of importance when considering the differences in disease levels.

The condition factor reflects the nutritional status of the fish and may, therefore, be a factor contributing to outbreaks of diseases in some areas. Lymphocystis was found to be significantly negatively correlated to the mean condition factor of the dab in Areas 3 and 4 as was epidermal papilloma in Area 3. A negative correlation between lymphocystis, epidermal papilloma and skin ulcers and condition factor was observed at different locations along the German and Danish coastal waters (Möller 1981) and for lymphocystis in the German Bight (Vethaak et al. 1992).

In general, the condition factor for lymphocystis- and epidermal papilloma-affected fish was higher than for the unaffected fish but this difference was only significant for lymphocystis in Area 1. It is difficult to explain this observation. Fast-growing fish may be more susceptible to diseases than fish with a normal growth rate. In contrast, skin ulcerations showed a negative effect on the fish, reflected in the lower condition factor or fish with skin ulcers as compared to unaffected fish. The difference in the condition factor between ulcerated and healthy fish was significantly different in Areas 3 and 4 . This negative effect can probably be attributed to osmoregulatory problems due to a damaged epithelial lining.

Lymphocystis was found evenly distributed among males and females except in Area 3, where females had a significantly reduced risk of contracting the disease compared to males. Mellergaard \& Nielsen (1995) found an equal relative risk for both sexes in the Kattegat. The observation in Area 3 may be a coincidence.

Epidermal papilloma revealed a significant increase in the relative risk for females in Areas 1 and 2. Although the relative risk was greater for females, no statistical difference was observed in Areas 3 and 4. A similar pattern has been observed in the Kattegat (Mellergaard \& Nielsen 1995) and in the German Bight (Dethlefsen et al. 1987). There are no obvious reasons why females should be more susceptible to epidermal papilloma than males. At the time of year when the present investigations took place, the fish were in the post-spawning period, during which time their condition is generally poor. This poor condition might explain the difference. However, one would then also expect an elevated risk of contracting lymphocystis, which was not observed.

The relative risk of contracting skin ulcerations was found to be significantly higher only for females in Areas 2 and 4 while slightly lower in the other areas. In the Kattegat region female dab had a significantly higher risk than males of developing skin ulcers (Mellergaard \& Nielsen 1995). Many of the skin ulcers observed during this study looked like skin abrasions, indicating that they may originate from traumatic skin damage probably caused by fishing gear. Most ulcerated fish were within the length range 18 to $23 \mathrm{~cm}$, a size which enables some of them to escape the net meshes of commercial trawls, or fish of this size might have been discarded if caught. Fishery-induced skin injuries have been shown to be correlated with the length of the fish (Lüdemann 1993). In general, female $\mathrm{dab}$ are longer than males and this may explain the higher risk observed for females in Areas 2 and 4 . There is no obvious explanation why females had a lower risk in the other areas.

The mean age of diseased fish was significantly higher compared to unaffected fish for all 3 diseases examined indicating that it is mainly older fish that become diseased.

The present study demonstrated marked geographical differences in the disease levels in dab. Areas such as the German Bight and the west coast of Denmark, having suffered from oxygen deficiency, showed sig- 
nificantly higher prevalence of lymphocystis and epidermal papilloma compared to an unaffected area like the Skagerrak. Although environmental stress often has a multifactorial background, the impact of oxygen depletion may be of major importance (Sindermann 1984). Therefore, there is a risk that the increased eutrophication of estuarine and coastal waters may be the most important danger to the health status of wild fish populations.

Acknowledgements. We thank Ms I. Hornum for excellent technical assistance, $\mathrm{Mr} \mathrm{O}$. V. Olsen for extracting oxygen data from the ICES Hydrographic Service Database, Dr I. Jenkinson for correcting the English language and the crew of RV 'Dana' for excellent collaboration during the cruises.

\section{LITERATURE CITED}

Anonymous (1989) Methodology of fish disease surveys. ICES Coop Res Rep 166:1-33

Banning P van (1987) Long-term recording of some fish diseases using general fishery research surveys in the southeast part of the North Sea. Dis Aquat Org 3:1-11

Bucke D, Nicholson MD (1987) Fish disease investigations in the Irish Sea. Comm Meet Int Counc Explor Sea C.M.ICES 1987/E:19

Bucke D, Norton MG, Rolfe MS (1983) The field assessment of effects of dumping wastes at sea: II. Epidermal lesions and abnormalities of fish in the outer Thames Estuary. Fish Res Tech Rep 72:1-16

Bucke D, Vethaak AD, Lang T, Mellergaard S (1996) Common diseases and parasites of fish in the North Atlantic: training guide for identification. Tech Mar Environ Sci 19:1-27

Christensen NO (1980) Diseases and anomalies in fish and invertebrates in Danish littoral regions which might be connected with pollution. Rapp P-V Réun Cons Int Explor Mer 179:103-109

Dean AG, Dean JA, Coulombier D, Brendel KA, Smith DL, Burton AH, Dicker RC, Sullivan K, Fagan RF, Arner TG (1994) Epi Info, version 6.01: a word processing, database and statistics programme for epidemiology on microcomputers. Centers for Disease Control and Prevension, Atlanta, GA

Despres-Patanjo L, Ziskowski J, Murchelano RA (1982) Distribution of fish diseases monitored on stock assessment cruises in the western North Atlantic. Comm Meet Int Counc Explor Sea C.M.-ICES 1982/E:30

Dethlefsen $V$ (1980) Observations on fish diseases in the German Bight and their possible relations to pollution. Rapp P-V Réun Cons Int Explor Mer 179:110-117

Dethlefsen V (1984) Diseases in North Sea fishes. Helgol Meeresunters 37:353-374

Dethlefsen V (1990) Ten years fish disease studies of the Institute für Küsten- und Binnenfischerei. Arch FischWiss 40:119-132

Dethlefsen V, Watermann B (1982) Diseases of major fish species in western Baltic Sea. Comm Meet Int Counc Explor Sea C.M.-ICES 1982/E: 19

Dethlefsen V, Watermann B, Hoppenheit M (1987) Diseases of North Sea dab (Limanda limanda L.) in relation to biological and chemical parameters. Arch FischWiss 37 : $107-237$
Dethlefsen $V$, Westernhagen $H$ von (1983) Oxygen deficiency and effects on bottom fauna in the eastern German Bight 1982. Meeresforsch 30:42-53

Dyer MF, Pope JG, Fry PD, Law RJ, Portmann JE (1983) Changes in fish and benthos catches off the Danish coast in September 1981. J Mar Biol Assoc UK 63:767 - 775

Johnstone J (1905) Internal parasites and diseased conditions of fishes. Rep Lancs Sea-Fish Lab 13:98-120

Johnstone J (1925) Malignant tumours in fishes. Rep Lancs Sea-Fish Lab 33:105-136

Larsen JL, Mellergaard S (1981) Microbiological and hygienic problems in marine aquaculture: furunculosis and vibriosis in rainbow trout (Salmo gairdneri). Bull Eur Assoc Fish Pathol 1:29-32

Larsson $\AA$, Lethinen KJ, Haux C (1980) Biochemical and hematological effects of a titanium dioxide industrial effluent on fish. Bull Environ Contam Toxicol 25: $427-435$

Lindesjöö E, Thulin J (1994) Histopathology of skin and gills of fish in pulp mill effluents. Dis Aquat Org 18:81-93

Lüdemann K (1993) Fishery-induced skin injuries in flatfish from the by-catch of shrimpers. Dis Aquat Org 16:127-132

Martin SW, Meek AH, Willeberg P (1987) Veterinary epldemiology. Iowa State University Press, Ames

McArdle J, Parker M, Martyn C, Rafferty D (1982) A survey of diseases of marine flatfish from the east coast of Ireland in 1981. Comm Meet Int Counc Explor Sea C.M.-ICES 1982/E:47

McIntyre AD, Pearce JB (1980) Biological effects of marine pollution and the problems of monitoring. Rapp P-V Réun Cons Int Explor Mer 179:1-346

Mellergaard S, Nielsen E (1984) Preliminary investigations on the eastern North Sea and the Skagerrak dab (Limanda limanda) populations and their diseases. Comm Meet Int Counc Explor Sea C.M.-ICES 1984/E:28

Mellergaard S, Nielsen E (1985) Fish diseases in the eastern North Sea dab (Limanda limanda) populations with special reference to the epidemiology of epidermal hyperplasias/papillomas. Comm Meet Int Counc Explor Sea C.M.-ICES 1985/E:14

Mellergaard S, Nielsen E (1987) The influence of oxygen deficiency on the dab population in the eastern North Sea and the southern Kattegat. Comm Meet Int Counc Explor Sea C.M.-ICES 1987/E:6

Mellergaard S, Nielsen E (1990) Fish disease investigations in Danish coastal waters with special reference to the impact of oxygen deficiency. Comm Meet Int Counc Explor Sea C.M.-ICES 1990/E:6

Mellergaard S, Nielsen E (1995) Impact of oxygen deficiency on the disease status of common dab Limanda limanda. Dis Aquat Org 22:101-114

Mellergaard S, Nielsen E (1996) Epidemiology of X-cell gill disease in common dab Limanda limanda. Dis Aquat Org 25:107-116

Möller H (1981) Fish diseases in German and Danish coastal waters in summer 1980. Meeresforsch 29:1-16

Möller H (1984) Dynamics of fish diseases in the lower Elbe River. Helgol Meeresunters 37:389-413

Möller H (1990) Association between diseases in flounder (Platicthys flesus) and environmental conditions in the Elbe estuary, FRG. J Cons Int Explor Mer 46:187-199

Möller H, Anders K (1983) Diseases and parasites of marine fishes. Verlag Moller, Kiel

Sindermann CJ (1984) Fish and environmental impacts. Arch FischWiss 35:125-160

Snieszko SF (1974) The effect of environmental stress on outbreaks of infectious diseases of fish. J Fish Biol 6:197-208 
Strange RJ, Schreck CB, Golden JT (1977) Corticoid stress responces to handling and tempera ture in salmonids. Trans Am Fish Soc 106:213-218

Vethaak AD (1991) Fish disease monitoring in the Dutch part of the North Sea in relation to the dumping of waste from titanium dioxide production. Chem Ecol 5:149-170

Vethaak AD (1992) Diseases of flounder (Platichthys flessus L.) in the Dutch Wadden Sea and their relation to stress factors. Neth J Sea Res 29:257-272

Vethaak AD (1993) Prevalence of fish diseases with reference

Responsible Subject Editor: Carl Schreck, Corvallis, Oregon, USA to pollution of Dutch coastal waters. Rivo-Rep CA 85-01/ $\mathrm{E}: 1-70$

Vethaak AD, Bucke D, Lang T, Wester PW, Jol J, Carr M (1992) Fish disease monitoring along a pollution transect: a case study using dab Limanda limanda in the German Bight. Mar Ecol Prog Ser 91:173-192

Wedemeyer G (1970) The role of stress in the disease resistance of fishes. In: Snieszko SF (ed) A symposium on diseases of fishes and shelltishes. American Fisheries Society, Washington, p 30-35

Manuscript received: July 31, 1996

Revised version accepted: April 7, 1997 